\title{
What is the effect of university education on chances to be self-employed in transitional countries?: Instrumental variable analysis of cross-sectional sample of 29 nations
}

\author{
Nazim Habibov ${ }^{1}$ - Elvin Afandi ${ }^{2}$ Alex Cheung ${ }^{3}$
}

Published online: 20 August 2016

(C) The Author(s) 2016. This article is published with open access at Springerlink.com

\begin{abstract}
We used a high-quality cross-sectional data set that covers a diverse set of 29 transitional countries, to find the effect of education of probability of people being selfemployed using standard probit models and instrumental variable biprobit that address endogeneity. Our findings suggest a negative effect of university education on the propensity of being self-employed. This finding remains the same for the single-stage model (i.e. standard probit) and the instrumental variable model (i.e. biprobit). We found strong endogeneity in the estimation of education effect on the propensity of being self-employed, ignoring which renders estimations biased. Regression models, which do not address endogeneity tend to underestimate the negative effect of the education on the probability of being self-employed in the countries of transition. Researchers should use alternative approaches to reduce endogeneity, such as instrumental variables and longitudinal analysis.
\end{abstract}

Keywords Education Endogeneity - Instrumental variables · Self-employment · Transitional countries

Nazim Habibov

habibov@yahoo.com; nnh@uwindsor.ca

Elvin Afandi

e.afandi@yahoo.com

Alex Cheung

cheun113@uwindsor.ca

2 The Islamic Corporation for the Development of the Private Sector, Islamic Development Bank Group, Level 13, Menara Bank Pembangunan, Jalan Raja Abdullah, Kuala Lumpur, Federal Territory of Kuala Lumpur 50300, Malaysia

3 University of Windsor, 401 Sunset Avenue, Windsor, ON, Canada N9C4E1 


\section{Introduction}

What is the effect of university education in transitional countries on the likelihood of being self-employed? Do individuals with university education have higher or lower probability to be self-employed versus being wage-earners in these countries? Does such probability vary across transitional regions?

Answering these questions are important since developing free private entrepreneurship has been one of the most important features of transition from a centrally-planned economy to a market one (Nikolova et al. 2012). The success of economic transition is strongly associated with the level of entrepreneurship (McMullen 2011). New entrepreneurs can find a niche in businesses that did not exist before transition or were stagnant under centrally-planned systems (Berkowitz and DeJong 2011). New entrepreneurial enterprises are more efficient with sales, and employment increases faster in these enterprises compared to state-owned or privatized companies (McMillan and Christopher 2002). Private entrepreneurship provides an important protection again income shocks associated with transitional processes by providing an alternative source of income and employment (George et al. 2012). Consequently, McMillan and Woodruff (2002, p. 154) concluded, "the success or failure of a transition economy can be traced in large part to the performance of its entrepreneurs".

Against this background that highlights the importance of the entrepreneurship, the objective of this paper is to assess the effect of higher education on probability of selfemployment in a diverse sample of 29 post-communist transitional countries. To study the effect of education is important since it can directly be manipulated and influenced by policy measures (Heyneman 2010; van der Zwan et al. 2013). In general, human capital theory postulates the positive return of higher level of education for wage earners and self-employed, although no such theory has yet been developed for the effects of education on the choice of self-employment (Block et al. 2011). Empirical findings regarding the effect of higher education on self-employment are far from conclusive (Dickson et al. 2008; Grilo and Thurik 2005; Parker 2009). Some studies demonstrate that higher education allows for the obtainment of skills and know-how valuable for self-employed (Davidsson and Honig 2003; Tamasy 2006; Klaesson and Larsson 2014). They have reported positive effects of education on the propensity of self-employment. Other studies demonstrate that higher education weakens start up intentions (Álvarez et al. 2013; Christelis and Fonseca 2015; Tamvada 2010; Uhlaner and Thurik 2004). They have reported negative effects of education on the propensity of being self-employed. Yet, other studies argue that education may lead to skills that are helpful for both self-employed and wage-earners, and therefore there is no straightforward association between high education and individuals' probability of being an entrepreneur or a wage-earner (Gimeno et al. 1997; Lee 1999).

Although there are a few studies, which focused on the determinants of entrepreneurial choice in transitional countries, the direct effect of high education on selfemployment is under researched (van der Zwan et al. 2013). The one reason is the lack of reliable high-quality data that would allow studying the effects of education on selfemployment on a diverse sample of transitional countries (Nikolova et al. 2012). The specificities of transitional economics, such as under-reformed educational systems, lack of trust in people and institutions, and economic and political instability suggest that the findings about the effect of education on self-employment choice made in more 
developed established democracies may not be automatically apply to transitional countries (Anderson and Heyneman 2005; George et al. 2012).

To cover the gap in the current literature, this article has two main objectives. First, to analyze the effect of university education on probability of being self-employed using a large data set which cover a diverse set of 29 transitional countries. Second, to employ IV method to address endogeneity. Endogeneity arises due to omitted explanatory variables, which may potentially influence both educational attainment and choice of self-employment. For instance, potential omitted variables such as, ability, intelligence, and motivation might simultaneously affect probability of obtaining higher education and the choice of being self-employed (Bauer and Chytilová 2010; Block et al. 2012; Parker 2009). Ignoring endogeneity, which occurred by omitted variables, led to biased estimates even for large samples (Block et al. 2011; Masakure 2015).

\section{Conceptual framework}

In this paper we hypothesize that university education has negative effect on probability of being self-employed in transitional countries. The specific hypothesis, which we test in this study, can be articulated as follows:

Hypothesis 1: "University education has negative effect on probability of being self-employed in transitional countries".

The negative effect of university education on probability of being self-employed in transitional countries can be explained by two main reasons. First, transitional countries inherited an educational system that was especially tailored to produce a set of skills which were required for a centrally-planned economy (Habibov 2010; Sabirianova 2002; Silova et al. 2007). Such set might be inappropriate to the new labor market circumstances inasmuch as it does not provide confidence, knowledge, and know-how needed to set up and manage their own business. At the same time, negative attitude to self-employment could further be reinforced by university education in transitional countries, which traditionally has been focused on enabling students to secure stable jobs (Bilić et al. 2011).

Second, individuals with high education who invested time and efforts to get university education are reluctant to move to self-employment (Alexeev and Kaganovich 1998; Habibov 2012). Individuals with a university education may also better understand specific risks associated with establishing and operating self-owned enterprises in uncertain and unstable socio-economic and regulatory conditions of transitional countries.

Third, in transitional countries, individuals with high education have more taste for leisure than individuals without high education (Mussurov and Arabsheibani 2015). Consequently, individuals with high education may deliberately favor under-employment, for instance, by being employed in government bureaucracy.

In addition, the problem of establishing the effect of education on the probability of being self-employed in transitional countries goes beyond the lack of reliable data, as isolating the effect of higher education on probability of self-employment is difficult given the strong endogeneity (Van der Sluis et al. 2008). A few studies, which 
addressed endogeneity in the effect of education on probability of self-employment in developed countries, have confirmed the importance of the omitted variable problem (Block et al. 2011, 2012; Parker and Van Praag 2006, 2010, Parker and van Praag 2010).

Perhaps due to endogeneity, the results of previous studies on the effect of education on self-employment in transitional countries produced inconclusive and contradictory results. Thus, Dutz et al. (2013), Karpinska et al. (2012) and Nikolova et al. (2012) have found that higher education in transitional countries is associated with higher probability of being self-employed. By contrast, Cho et al. (2015), Vakhitova and Coupe (2014), and Mussurov and Arabsheibani (2015) have found that higher education is associated with lower probability of being self-employed.

To the best of our knowledge there have been no studies on the effect of education on self-employment choice that addresses endogeneity in a diverse sample of transitional countries. In fact, we are only aware of one study by Block et al. (2011) that addresses endogeneity of education effect on self-employment in transitional countries. However, the authors covered only a handful of transitional countries, namely, the Czech Republic, Estonia, Latvia, Lithuania, and Hungary.

\section{Method}

For this study, we use the life in transition country survey (henceforth, LITS) conducted by the European Bank for Reconstruction and Development and the World Bank (EBRD 2011) that included over 29 transitional countries in 2010. ${ }^{1}$ The survey collects information about the work status, risk acceptance, trust in people and institutions, and educational attainments of respondent and their parents. Approximately 1000 household were interviewed in each country by specially-trained interviewers, with total sample size reaching 31,089 respondents.

In this study, we are interested in the effect of educational attainment on the choice of self-employment. Following the previous studies, we restricted our sample to those who worked for wage, as either self-employed or in paid employment during last 12 months at the time of interviewing, by excluding students, retirees, unemployed, respondents who refused to provide an answer, and missing answers (Block et al. 2011). This studies sample was reduced to 15,111 respondents.

The outcome variable for this study is a binary variable, self-employed, that captures whether the respondent is self-employed or not. If the respondent was self-employed, we assign 1 to the binary self-employed variable. The predictor variable for this study is university education. ${ }^{2}$ A value of 1 is given if a respondent's highest level of educational attainment includes bachelor, master or $\mathrm{Ph} . \mathrm{D}$. degrees, and takes value of 0 if educational attainment is lower. We control for the socio-demographic variables of age and gender, which is commonly used for self-employment study (Grilo and Thurik 2008; Johansson 2000). We also

\footnotetext{
${ }^{1}$ The countries cover by the LITS include Albania, Armenia, Azerbaijan, Belarus, Bosnia, Bulgaria, Croatia, Czech Republic, Estonia, Georgia, Hungary, Kazakhstan, Kyrgyzstan, Kosovo, Latvia, Lithuania, Macedonia, Montenegro, Moldova, Mongolia, Poland, Romania, Russia, Serbia, Slovakia, Slovenia, Tajikistan, Ukraine, and Uzbekistan.

${ }^{2}$ The LITS does not provides education in years for the respondents.
} 
control for general trust in people and institutions, and risk acceptance, as previous studies found that they are positively associated with probability of being selfemployed (Andriani 2015; Cramer et al. 2002; Hamilton 2000; Nakhaie et al. 2009). Finally, we control for country fixed effects by including the dummy variables fo $r$ countries into regression models. The relationship between the outcome, the predictor, the control, and instrumental variables is illustrated by Fig. 1, while summary statistics is provided in Table 1.

Since our outcome variable is binomial we commence with estimation of standard binomial probit model. This model ignores endogeneity, and hence could be biased. To adjust for endogeneity, we use instrumental variable bivariate probit. In simplified form, the biprobit model can be presented in the following form:

$$
\begin{gathered}
Y^{*}=X \beta_{y}+D^{*} \alpha_{y}+\varepsilon \\
D^{*}=X \beta_{d}+Z \alpha_{d}+\varepsilon
\end{gathered}
$$

where both $Y^{*}$ and $D^{*}$ are latent variables that are not observable but depends on the observable outcome variable $\mathrm{Y}$ and predictor $\mathrm{D}$ respectively. The variable $\mathrm{X}$ is covariates, and is $\alpha$ a vector of instruments, $\beta_{y}$ and $\beta_{d}$ are coefficients estimated using maximum likelihood method. The purpose of biprobit is to evaluate the following equation:

$$
\begin{gathered}
\operatorname{Prob}(Y=1)=\varphi\left(Y^{*}\right) \\
\operatorname{Prob}(D=1)=\varphi\left(D^{*}\right)
\end{gathered}
$$

where $\varphi($.$) is the cumulative distribution function of standard normal distribution.$

The difficulty of using the instrumental variable approach for analysis is that instruments have to be correlated with the predictor variables, and at the same

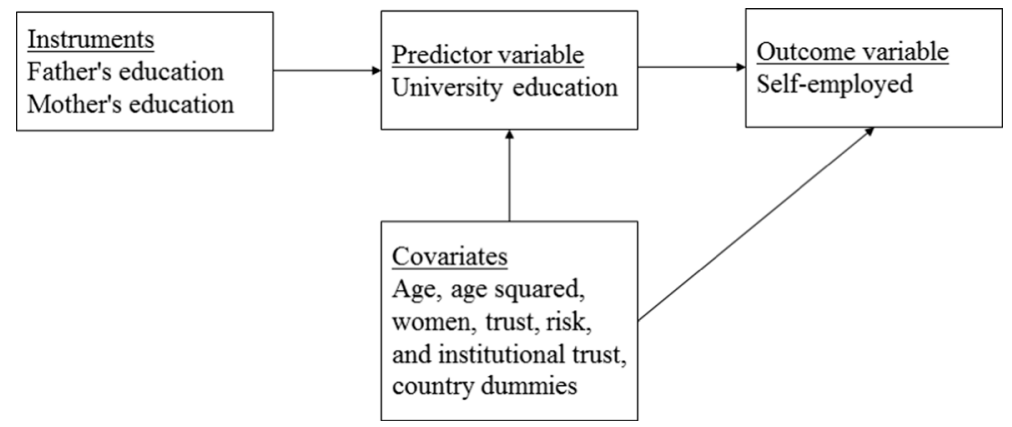

Fig. 1 Relationship between the outcome, the predictor, the instruments and the covariates 
Table 1 Summary statistics

\begin{tabular}{|c|c|c|c|c|c|c|}
\hline Variable & Description & Mean & Prop. & St. err & Min. & Max. \\
\hline \multicolumn{7}{|c|}{ Outcome variable } \\
\hline $\begin{array}{l}\text { Self- } \\
\text { employed }\end{array}$ & $\begin{array}{l}\text { Binary variable }=1 \text { if respondent is } \\
\text { self-employed }\end{array}$ & & $19.28 \%$ & 0.0032 & & \\
\hline \multicolumn{7}{|c|}{ Predictor variable } \\
\hline $\begin{array}{l}\text { University } \\
\text { education }\end{array}$ & $\begin{array}{l}\text { Binary variable }=1 \text { if respondent } \\
\text { has a university degree }\end{array}$ & & $27.62 \%$ & 0.0036 & & \\
\hline \multicolumn{7}{|l|}{ Covariates } \\
\hline Age & Age of the respondent & 40.21 & & 12.62 & 17 & 99 \\
\hline $\begin{array}{l}\text { Age } \\
\text { squared }\end{array}$ & Age of the respondent square & 1776.05 & & 1091.02 & 289 & 9801 \\
\hline Women & $\begin{array}{l}\text { Binary variable }=1 \text { if respondent } \\
\text { is a female }\end{array}$ & & $54.75 \%$ & 0.0040 & & \\
\hline Trust & $\begin{array}{l}\text { Trusting people index, higher the } \\
\text { index is, higher chance to trust } \\
\text { other people }\end{array}$ & 3.00 & & 1.02 & 1 & 5 \\
\hline Risk & $\begin{array}{l}\text { Willingness to take risks index, } \\
\text { higher the index is, higher the } \\
\text { chance that respondent is willing } \\
\text { to take risks }\end{array}$ & 5.13 & & 2.49 & 1 & 10 \\
\hline $\begin{array}{l}\text { Institutional } \\
\text { trust }\end{array}$ & $\begin{array}{l}\text { Composite index of trust with respect } \\
\text { to the country's central government, } \\
\text { regional government, local } \\
\text { government, parliament, political } \\
\text { parties, court, and police. The index } \\
\text { varies from } 0 \text { to } 7 \text {, where } 0 \text { indicates } \\
\text { the lowest trust and } 7 \text { denotes the } \\
\text { greatest trust in institutions. }\end{array}$ & 1.98 & & 2.26 & 0 & 7 \\
\hline \multicolumn{7}{|l|}{ Instruments } \\
\hline $\begin{array}{l}\text { Father's } \\
\text { education }\end{array}$ & Father's full-time education in years & 10.21 & & 3.94 & 0 & 50 \\
\hline $\begin{array}{l}\text { Mother's } \\
\text { education }\end{array}$ & Mother's full-time education in years & 9.75 & & 3.93 & 0 & 44 \\
\hline
\end{tabular}

time the effect of the instruments on outcome variable have to be indirect, i.e. the effect of the instruments on the outcome variable has to be captured by the predictors (Axinn and Barber 2001; Winship and Morgan 1999). Following previous studies, the instruments are family background characteristics, namely the years of education of the father and mother (Ashenfelter and Zimmerman 1997; Lemke and Rischall 2003). Theoretically, it is well-established that on average higher education of parents is associated with higher education of children (Currie and Moretti 2003; Farré et al. 2012; Plug and Vijverberg 2003). Earlier studies, which used the instrumental variable approach showed that family education is highly correlated to education of parents (Blackburn and Neumark 1993; Masakure 2015; Parker and Van Praag 2006). Perhaps more importantly, the recent studies on the effect of education on occupational choice suggest that parent 
education is a valid instrument for education (Block et al. 2011, 2012; Masakure 2015). Consequently, we hypothesize that parent education is a valid instrument for education of their children.

We empirically tested the validity of the instruments in several ways. First, to test whether the instruments are associated with the outcome variable, we calculated the Person's correlation between the instruments and outcome variable. The correlation for father's full-time education year is $-0.11(p=0.000)$ with the self-employed, while the correlation for mother's full-time education year with the self-employed is -0.13 $(p=0.000)$. The correlations for the instruments with self-employed are considered to be negligible (Mukaka 2012), which suggests that instruments and outcome variable are not strongly associated.

Second, to test whether the instruments are not jointly correlated with the outcome variable, we estimated the Sargan and Basmann tests (Basmann 1960; Sargan 1958). Non-significant $\chi^{2}$ for both tests, reported in Table 2, indicate that the instruments are not jointly correlated with the outcome variable.

To test whether instruments are correlated with the predictor, we conducted firststage robust F-statistic test. A significant robust F statistics, which is higher than a rule of thumb value of 10 , indicates that instruments are not weakly correlated with the predictor (Cameron and Trivedi 2010; Stock et al. 2002).

To test that the instruments are not weakly correlated to the predictor, we compute the minimum eigenvalue statistics and compared them to the Stock and Yogo's critical values. The minimum eigenvalue statistics values reported for all biprobit models are higher than Stock and Yogo's critical values, which indicate that instruments are not weakly correlated with the predictor (Cragg and Donald 1993). All the above-tests are estimated by running 2SLS. Although these tests were especially developed for nonlinear models, their estimation is important in the assessing the biprobit (Nichols 2007).

To assess whether the biprobit models are preferred over single-stage probit models, we performed Wald test of endogeneity for biprobit models. In all our estimations, significant results of the tests indicate that the results of single-stage probit model are biased, and biprobit model should be used instead (Knapp and Seaks 1998).

Probit and biprobit models are estimated using -probit- and -biprobit- commands in Stata 13 software package. Since some controls, such as general trust in people and institutions, and risk acceptance, can be correlated to each other we included them into regression hierarchically.

We commence with estimation of single-stage probit models for the total sample and then move to estimation of biprobit models total sample. To further explore the spatial variation in the effect of university education on selfemployment we split sample into three groups in accordance with EBRD classification: (1) the former Soviet Union (FSU) region encompassing Armenia, Azerbaijan, Belarus, Georgia, Kazakhstan, Kyrgyzstan, Moldova, Russia, Tajikistan, Ukraine, Uzbekistan and Mongolia, which was not officially part of the former Soviet Union; (2) the Southern Europe (SE) region encompassing Albania, Bosnia, Bulgaria, Croatia, Macedonia, Romania, Serbia, and Montenegro; (3) the Central Europe (CE) region including the Czech Republic, Estonia, Hungary, Latvia, Lithuania, Poland, Slovakia, Slovenia, and Kosovo. 
Table 2 Results of probit and biprobit models

\begin{tabular}{|c|c|c|c|c|c|c|}
\hline & \multicolumn{3}{|l|}{ Probit } & \multicolumn{3}{|l|}{ Biprobit } \\
\hline & Model 1 & Model 2 & Model 3 & Model 4 & Model 5 & Model 6 \\
\hline University education & $\begin{array}{l}-0.073 * * * \\
(0.009)\end{array}$ & $\begin{array}{l}-0.083^{* * *} \\
(0.009)\end{array}$ & $\begin{array}{l}-0.083^{* * *} \\
(0.009)\end{array}$ & $\begin{array}{l}-0.208^{* * *} \\
(0.032)\end{array}$ & $\begin{array}{l}-0.269 * * * \\
(0.036)\end{array}$ & $\begin{array}{l}-0.269 * * * \\
(0.036)\end{array}$ \\
\hline Age & $\begin{array}{l}-0.002 \\
(0.001)\end{array}$ & $\begin{array}{l}-0.001 \\
(0.001)\end{array}$ & $\begin{array}{l}-0.001 \\
(0.001)\end{array}$ & $\begin{array}{l}-0.001 \\
(0.002)\end{array}$ & $\begin{array}{l}-0.001 \\
(0.002)\end{array}$ & $\begin{array}{l}-0.001 \\
(0.002)\end{array}$ \\
\hline Age squared & $\begin{array}{l}0.000 * * \\
(0.000)\end{array}$ & $\begin{array}{l}0.000 * * \\
(0.000)\end{array}$ & $\begin{array}{l}0.000 * * \\
(0.000)\end{array}$ & $\begin{array}{l}0.000 * \\
(0.000)\end{array}$ & $\begin{array}{l}0.000 \\
(0.000)\end{array}$ & $\begin{array}{l}0.000 \\
(0.000)\end{array}$ \\
\hline Women & $\begin{array}{l}-0.056^{* * *} \\
(0.007)\end{array}$ & $\begin{array}{l}-0.047 * * * \\
(0.007)\end{array}$ & $\begin{array}{l}-0.047 * * * \\
(0.007)\end{array}$ & $\begin{array}{l}-0.050 * * * \\
(0.009)\end{array}$ & $\begin{array}{l}-0.035^{* * *} \\
(0.009)\end{array}$ & $\begin{array}{l}-0.035^{* * *} \\
(0.009)\end{array}$ \\
\hline Trust & & $\begin{array}{l}0.002 \\
(0.003)\end{array}$ & $\begin{array}{l}0.002 \\
(0.003)\end{array}$ & & $\begin{array}{l}0.007 \\
(0.004)\end{array}$ & $\begin{array}{l}0.007 \\
(0.004)\end{array}$ \\
\hline Risk & & $\begin{array}{l}0.015 * * * \\
(0.002)\end{array}$ & $\begin{array}{l}0.015 * * * \\
(0.002)\end{array}$ & & $\begin{array}{l}0.019 * * * \\
(0.002)\end{array}$ & $\begin{array}{l}0.019 * * * \\
(0.002)\end{array}$ \\
\hline Institutional trust & & & $\begin{array}{l}-0.001 \\
(0.002)\end{array}$ & & & $\begin{array}{l}0.001 \\
(0.002)\end{array}$ \\
\hline Country fixed effect & Yes & Yes & Yes & Yes & Yes & Yes \\
\hline Observations & 15,102 & 13,985 & 13,985 & 11,402 & 10,609 & 10,609 \\
\hline Wald $\chi^{2}$ & $1502.50 * * *$ & $1757.07 * * *$ & $1915.30 * * *$ & $15580.43^{* * * *}$ & $18671.08 * * *$ & $19457.13 * * *$ \\
\hline \multicolumn{7}{|c|}{ First-stage regression summary statistics } \\
\hline Robust F statistic & & & & $359.93 * * *$ & $316.70 * * *$ & $314.86^{* * *}$ \\
\hline $\begin{array}{l}\text { Minimum } \\
\text { eigenvalue } \\
\text { statistic }\end{array}$ & & & & 491.96 & 426.61 & 426.9 \\
\hline $\begin{array}{l}\text { Stock and Yogo's } \\
\text { statistic }\end{array}$ & & & & 19.93 & 19.93 & 19.93 \\
\hline \multicolumn{7}{|c|}{ Tests of overidentifying restrictions } \\
\hline Sargan $\chi^{2}$ & & & & 1.26 & 1.93 & 1.91 \\
\hline Basmann $\chi^{2}$ & & & & 1.25 & 1.92 & 1.91 \\
\hline \multicolumn{7}{|l|}{ Test of endogeneity } \\
\hline Wald test of rho $=0$ & & & & $16.74 * * *$ & $21.59 * * *$ & $21.75 * * *$ \\
\hline
\end{tabular}

Note. $* p<0.05, * * p<0.01, * * * p<0.001$

\section{Results}

\section{Total sample}

The marginal effects of single-stage probit models, which ignore endogeneity, are reported in Model 1-3 in Table 2. Model 1 serves as our baseline estimation, and includes only respondent's education and socio-demographic control such as age, age squared, and gender. The model indicates that the university degree reduces the probability of self-employment by $7.3 \%$ points. Being a women reduces probability of self-employment by 5.6 percentage points. 
After controlling for trust in people and risk acceptance of respondent in Model 2, the negative effect of university education on the probability of self-employment increased to 8.3 percentage points. The increase in risk score is associated with higher probability to be self-employed, while trust in people is not significant. The effect of other covariates is the same as in the previous model.

Index of institutional trust is added in Model 3. The effect of institutional trust is not significant. The direction and the magnitude of the effect of the university degree on self-employment remain the same as in the previous model. The effects of other covariates are the same as in the previous model.

The marginal effects of biprobit models, which address endogeneity, are reported in Models 4-6. Model 4 serves as our benchmark model, which includes only respondent's education and socio-demographic controls such as, age, age squared, and gender. It indicates that the university degree leads to the reduction in propensity of being selfemployed by 20.8 percentage points. After we control for trust in people and risk acceptance of respondent in Model 5, the negative effect of university education reaches approximately 26.9 percentage points. Adding institutional trust as a control in Model 6 did not change the direction and the magnitude of the effect of the university education.

To quantify the impact of endogeneity, we compare the results of the effect of university education suggested by probit with the results suggested by biprobit. As shown, the negative effect of university education in Models 6 is approximately 3.2 times higher than Model 3. The impact of endogeneity in our study is in line with that reported by previous studies. Thus, Masakure (2015) reported an approximate 4 times difference between single-stage and instrumental variable models, while Block et al. (2011) found about 10 times difference.

\section{Regional samples}

The regional probit and biprobit results are reported in Table 3. The probit and biprobit models for the countries of the former Soviet Union are reported in Model 7 and 8. The results suggest that university education reduces the propensity of being selfemployment by 10.2 and 33.4 percentage points in the FSU region. The probit and biprobit results of the Southern Europe region are reported in Model 9 and 10. The results suggest that a university education reduces the probability of being selfemployment by 12.7 and 32.5 percentage points respectively. The results of probit and biprobit for the Central Europe region are reported in Model 11 and 12. They suggest that a university education reduces the probability of being self-employment by 2.3 and 5.4 percentage points. However, the reduction is not significant in both probit and biprobit.

In terms of difference between single-stage probit and biprobit results, we find that effect of education, which suggested by biprobit, is approximately 3 times higher than the effect suggested by probit in all regions under investigation.

\section{Conclusion}

Despite the surge of empirical studies exploring the role of education in probability of being self-employed, limited evidence exists for post-communist transition countries 
Table 3 Results of probit and biprobit models for regions

\begin{tabular}{|c|c|c|c|c|c|c|}
\hline & \multicolumn{2}{|l|}{ FSU } & \multicolumn{2}{|l|}{ SE } & \multicolumn{2}{|l|}{$\mathrm{CE}$} \\
\hline & Model 7 & Model 8 & Model 9 & Model 10 & Model 11 & Model 12 \\
\hline University education & $\begin{array}{l}-0.102 * * * \\
(0.013)\end{array}$ & $\begin{array}{l}-0.334 * * * \\
(0.058)\end{array}$ & $\begin{array}{l}-0.127 * * * \\
(0.019)\end{array}$ & $\begin{array}{l}-0.325^{* * *} \\
(0.053)\end{array}$ & $\begin{array}{l}-0.023 \\
(0.013)\end{array}$ & $\begin{array}{l}-0.054 \\
(0.072)\end{array}$ \\
\hline Age & $\begin{array}{l}0.001 \\
(0.002)\end{array}$ & $\begin{array}{l}0.003 \\
(0.003)\end{array}$ & $\begin{array}{l}-0.006 * \\
(0.003)\end{array}$ & $\begin{array}{l}-0.006 \\
(0.003)\end{array}$ & $\begin{array}{l}-0.001 \\
(0.002)\end{array}$ & $\begin{array}{l}0.001 \\
(0.002)\end{array}$ \\
\hline Age squared & $\begin{array}{l}-0.000 \\
(0.000)\end{array}$ & $\begin{array}{l}-0.000 \\
(0.000)\end{array}$ & $\begin{array}{l}0.000 * * * \\
(0.000)\end{array}$ & $\begin{array}{l}0.000 * * * \\
(0.000)\end{array}$ & $\begin{array}{l}0.000 \\
(0.000)\end{array}$ & $\begin{array}{l}0.000 \\
(0.000)\end{array}$ \\
\hline Women & $\begin{array}{l}-0.050 * * * \\
(0.010)\end{array}$ & $\begin{array}{l}-0.036 * * \\
(0.013)\end{array}$ & $\begin{array}{l}-0.038 * \\
(0.016)\end{array}$ & $\begin{array}{l}-0.025 \\
(0.018)\end{array}$ & $\begin{array}{l}-0.049 * * * \\
(0.010)\end{array}$ & $\begin{array}{l}-0.046^{* * * *} \\
(0.013)\end{array}$ \\
\hline Trust & $\begin{array}{l}0.002 \\
(0.004)\end{array}$ & $\begin{array}{l}0.006 \\
(0.005)\end{array}$ & $\begin{array}{l}0.002 \\
(0.007)\end{array}$ & $\begin{array}{l}0.009 \\
(0.007)\end{array}$ & $\begin{array}{l}0.002 \\
(0.007)\end{array}$ & $\begin{array}{l}0.001 \\
(0.008)\end{array}$ \\
\hline Risk & $\begin{array}{l}0.013 * * * \\
(0.002)\end{array}$ & $\begin{array}{l}0.018 * * * \\
(0.003)\end{array}$ & $\begin{array}{l}0.014 * * * \\
(0.003)\end{array}$ & $\begin{array}{l}0.016^{* * *} \\
(0.003)\end{array}$ & $\begin{array}{l}0.020 * * * \\
(0.002)\end{array}$ & $\begin{array}{l}0.023 * * * \\
(0.004)\end{array}$ \\
\hline Institutional trust & $\begin{array}{l}-0.000 \\
(0.003)\end{array}$ & $\begin{array}{l}0.000 \\
(0.003)\end{array}$ & $\begin{array}{l}0.001 \\
(0.004)\end{array}$ & $\begin{array}{l}0.004 \\
(0.005)\end{array}$ & $\begin{array}{l}-0.003 \\
(0.002)\end{array}$ & $\begin{array}{l}-0.002 \\
(0.003)\end{array}$ \\
\hline Country fixed effect & Yes & Yes & Yes & Yes & Yes & Yes \\
\hline PSU fixed effect & No & No & No & No & No & No \\
\hline Observations & 5658 & 4251 & 3600 & 3168 & 4727 & 3190 \\
\hline Wald $\chi^{2}$ & $697.57 * * *$ & $5565.22 * * *$ & $338.95 * * *$ & $1404.95 * * *$ & $198.14 * * *$ & $365.85 * * *$ \\
\hline \multicolumn{7}{|c|}{ First-stage regression summary statistics } \\
\hline Robust F statistic & & $99.11 * * *$ & & $150.37 * * *$ & & $65.79 * * *$ \\
\hline $\begin{array}{l}\text { Minimum eigenvalue } \\
\text { statistic }\end{array}$ & & 157.67 & & 173.86 & & 107.17 \\
\hline Stock and Yogo's statistic & & 19.93 & & 19.93 & & 19.93 \\
\hline \multicolumn{7}{|c|}{ Tests of overidentifying restrictions } \\
\hline Sargan $\chi^{2}$ & & 0.002 & & 2.45 & & $6.07 *$ \\
\hline $\begin{array}{l}\text { Basmann } \chi^{2} \\
\text { Test of endogeneity }\end{array}$ & & 0.002 & & 2.43 & & $6.05 *$ \\
\hline Wald test of rho $=0$ & & $9.07 * *$ & & $14.15^{* * * *}$ & & $9.07 * *$ \\
\hline
\end{tabular}

Note. $* p<0.05, * * p<0.01, * * * p<0.001$

that also take into account the endogeneity issue. We used a high-quality data set that covers a diverse set of 29 transitional countries, to find the effect of education of probability of people being self-employed using standard probit models and instrumental variable biprobit that address endogeneity. The findings presented in this paper allow us to draw three important implications.

First, from the theoretical perspective, our findings suggest a negative effect of university education on the propensity of being self-employed. This finding remains the same for single-stage model (i.e. binomial probit) and instrumental variable model (i.e. biprobit). Furthermore, this finding remains the same for the total sample of transitional countries and for the former Soviet Union and the Southern Europe regions taken 
separately. As outlined in the conceptual framework the negative effect of university education on probability to be self-employed could be explained by the interplay of three main factors. Educational system is not well-tailored to provide students with skills and confidence in setting up and managing their own business. At the same time, that individuals with higher education who invested in obtaining higher education are reluctant to be self-employed in uncertain socio-economic and regulatory environment of transitional countries. Likewise, higher education increases preference for more leisure. However, in the Central Europe, where most countries are members of the European Union or candidates for the European Union, the negative effect of university education is not significant. It seems that the above-mentioned factors which explain negative effect of university of education in the former Soviet Union and the Southern Europe have relatively weaker effect in the Central Europe since this region is the most developed with better education system, more stable socio-economic and regulatory environment, and less taste for under-employment through government employment.

Second, from the practical perspective, our findings suggest that more efforts should be made to foster entrepreneurship through university education in transitional countries. Fortunately, there are examples of successful cooperation in developing new curriculum and syllabi between universities in developed and transitional countries through the partnership projects (Heyneman 2005). Such examples could be instrumental in bringing entrepreneurship education in transitional countries in line with those in developed countries of the Western Europe and North America. More specifically, entrepreneurship can be incorporated into university education as a matter of culture, as a matter of behavior, or as a matter of specific situations (Fayolle and Klandt 2006). Education centered on fostering entrepreneurship as a matter of culture incorporates a set of values, beliefs and attitudes which are usually associated with entrepreneurship. Promoting entrepreneurial mindset and spirit exemplifies fostering entrepreneurship as a matter of culture. Education centered on fostering entrepreneurship as a matter of behavior typically focuses on developing a particular set of skills related to setting up and managing their own business. Skills related to making decision in uncertain situations is an example of such skills. Lastly, fostering entrepreneurshiporiented education involves business skills such as the creation of new firms and corporate venturing.

Third, from the method perspective, our study demonstrates the existence of strong endogeneity in the estimation of education effect on the propensity of being selfemployed. Ignoring endogeneity renders estimations biased. Our empirical results show that the standard single-stage models that do not address endogeneity (e.g. standard binomial probit regression) should be used with caution when it comes to the estimation of the effect of education in transitional countries. Such standard models tend to underestimate the negative effect of the education on the probability of being selfemployed in the countries of transition. The researchers should use alternative approaches to reduce endogeneity, such as instrumental variables and longitudinal analysis.

Finally, this study has several important limitations. ${ }^{3}$ On the one hand, the negative relationship between high level of education and probability of being self-employed

\footnotetext{
${ }^{3}$ We are grateful to anonymous referees for pointing out to the alterative explanations of negative effect of education on self-employment.
} 
could be explained by the motive, for instance, opportunity versus necessity as possible motives for taking the decision to be self-employed. On the other hand, it is possible that individuals with a more balanced portfolio of human capital, social capital and experiences rather than with university education are more disposed to be entrepreneurs (Lazear 2005). In addition, one can speculate that the negative image of entrepreneurship and type of education could be important explanatory factors (Boissin et al. 2009). Unfortunately, we cannot test the above-discussed alternative explanations due to the data set limitations. Thus, testing the alternative explanations constitutes the agenda for the future studies.

Open Access This article is distributed under the terms of the Creative Commons Attribution 4.0 International License (http://creativecommons.org/licenses/by/4.0/), which permits unrestricted use, distribution, and reproduction in any medium, provided you give appropriate credit to the original author(s) and the source, provide a link to the Creative Commons license, and indicate if changes were made.

\section{References}

Alexeev, P., \& Kaganovich, M. (1998). Return of human capital under uncertain reform: good guys finish last. Journal of Economic Behavior and Organization, 37, 53-70.

Álvarez, G., Lago, C., \& Giráldez, M. (2013). Self-employment: transition and earnings differential. Revista de economía aplicada, 21, 61-90.

Anderson, K., \& Heyneman, S. (2005). Education and social policy in Central Asia: the next stage of the transition. Social Policy \& Administration, 39, 361-380.

Andriani, L. (2015). Tax morale and prosocial behaviour: evidence from a Palestinian survey. Cambridge Journal of Economics. doi:10.1093/cje/bev019.

Ashenfelter, O., \& Zimmerman, D. (1997). Estimates of the returns to schooling from sibling data: fathers, sons, and brothers. Review of Economics and Statistics, 79, 1-9.

Axinn, W., \& Barber, J. (2001). Mass education and fertility transition. American Sociological Review, 66, 481-505.

Basmann, R. (1960). On finite sample distributions of generalized classical linear identifiability test statistics. Journal of the American Statistical Association, 55, 650-659.

Bauer, M., \& Chytilová, J. (2010). The impact of education on subjective discount rate in Ugandan villages. Economic Development and Cultural Change, 58, 643-669.

Berkowitz, D., \& DeJong, D. (2011). Growth in post-Soviet Russia: a tale of two transitions. Journal of Economic Behavior \& Organization, 79, 133-143.

Bilić, A., Prka, A., \& Vidović, G. (2011). How does education influence entrepreneurship orientation? Case study of Croatia Management. Journal of Contemporary Management Issues, 16, Article 4.

Blackburn, M., \& Neumark, D. (1993). Omitted-ability bias and the increase in the return to schooling. Journal of Labor Economics, 11, 521-544.

Block, J., Hoogerheide, L., \& Thurik, R. (2011). Education and entrepreneurial choice: an instrumental variables analysis. International Small Business Journal, 31, 23-33.

Block, J., Hoogerheide, L., \& Thurik, R. (2012). Are education and entrepreneurial income endogenous? a Bayesian analysis. Entrepreneurship Research Journal, 2, 1-29.

Boissin, J., Branchet, B., Emin, S., \& Herbert, J. (2009). Students and entrepreneurship: a comparative study of France and the United States. Journal of Small Business \& Entrepreneurship, 22, 101-122.

Cameron, C., \& Trivedi, P. (2010). Microeconometrics using Stata. College Station: Stata Press.

Cho, Y., Robalino, D., \& Romero, J. (2015). Entering and Leaving Self-Employment: A Panel Data Analysis for 12 Developing Countries (No. 9358). IZA Discussion Papers.

Christelis, D., \& Fonseca, R. (2015). Labor market policies and self-employment transitions of older workers (No. 2015s-50). CIRANO.

Cragg, J., \& Donald, S. (1993). Testing identifiability and specification in instrumental variable models. Econometric Theory, 9, 222-240. 
Cramer, J., Hartog, J., Jonker, N., \& Van Praag, C. (2002). Low risk aversion encourages the choice for entrepreneurship: an empirical test of a truism. Journal of Economic Behavior \& Organization, 48, 29 36.

Currie, J., \& Moretti, E. (2003). Mother's education and the intergenerational transmission of human capital: Evidence from college openings. The Quarterly Journal of Economics, 118, 1495-1532.

Davidsson, P., \& Honig, B. (2003). The role of social and human capital among nascent entrepreneurs. Journal of Business Venturing, 18, 301-331.

Dickson, P., Solomon, G., \& Weaver, K. (2008). Entrepreneurial selection and success: does education matter? Journal of Small Business and Enterprise Development, 15, 239-258.

Dutz, M., Kauffmann, C., Najarian, S., Sanfey, P., \& Yemtsov, R. (2013). Labour market states, mobility and entrepreneurship in transition economies. Brazilian Journal of Business Economics, 4, $27-50$.

European Bank for Reconstruction and Development. (2011). Life in transition after the crisis. London: EBRD.

Farré, L., Klein, R., \& Vella, F. (2012). Does increasing parents' schooling raise the schooling of the next generation? evidence based on conditional second moments. Oxford Bulletin of Economics and Statistics, 74, 676-690.

Fayolle, A., \& Klandt, H. (2006). International entrepreneurship education - issues and newness. Cheltenham: Edward Elgar.

George, G., McGahan, A., \& Prabhu, J. (2012). Innovation for inclusive growth: towards a theoretical framework and a research agenda. Journal of Management Studies, 49, 661-683.

Gimeno, J., Folta, T., Cooper, A., \& Woo, C. (1997). Survival of the fittest? Entrepreneurial human capital and the persistence of underperforming firms. Administrative Science Quarterly, 42, 750-783.

Grilo, I., \& Thurik, R. (2005). Latent and actual entrepreneurship in Europe and the US: some recent developments. The International Entrepreneurship and Management Journal, 1, 441-459.

Habibov, N. (2010). An intertemporal evolution of inequality in Azerbaijan: 1995-2002. Problems of Economic Transition, 52, 51-77.

Habibov, N. (2012). How and why determinants of household welfare changed in Azerbaijan during the transition: lessons from national surveys. Problems of Economic Transition, 54, 3-52.

Hamilton, B. (2000). Does entrepreneurship pay? an empirical analysis of the returns to self-employment. Journal of Political Economy, 108, 604-631.

Heyneman, S. (2005). Post-graduate training and research in higher education management in Kazakhstan. Kazakh Journal on Higher Education, 3, 27-34.

Heyneman, S. (2010). A comment on the changes in higher education in the former Soviet Union. European Education, 42, 76-87.

Johansson, E. (2000). Self-employment and liquidity constraints: evidence from Finland. The Scandinavian Journal of Economics, 102, 123-134.

Karpinska, K., Maas, I., \& Jansen, W. (2012). Self-employment in post-communist economies: a crosscountry comparison, 1996-2005. European Societies, 14, 684-703.

Klaesson, J., \& Larsson, J. P. (2014). Education and self-employment propensity (No. 345). Royal Institute of Technology, CESIS-Centre of Excellence for Science and Innovation Studies.

Knapp, L., \& Seaks, T. (1998). A Hausman test for a dummy variable in probit. Applied Economics Letters, 5 , 321-323.

Lazear, E. P. (2005). Entrepreneurship. Journal of Labor Economics, 23(4), 649-680.

Lee, A. (1999). Empirical studies of self-employment. Journal of Economic Surveys, 13, 381-416.

Lemke, R., \& Rischall, I. (2003). Skill, parental income, and IV estimation of the returns to schooling. Applied Economics Letters, 10, 281-286.

Masakure, O. (2015). Education and entrepreneurship in Canada: evidence from (repeated) cross-sectional data. Education Economics, 23, 693-712.

McMillan, J., \& Christopher, W. (2002). The central role of entrepreneurs in transition economies. Journal of Economic Perspectives, 16, 153-170.

McMullen, J. (2011). Delineating the domain of development entrepreneurship: a market-based approach to facilitating inclusive economic growth. Entrepreneurship: Theory and Practice, 35, 185-193.

Mukaka, M. (2012). A guide to appropriate use of correlation coefficient in medical research. Malawi Medical Journal, 24, 69-71.

Mussurov, A., \& Arabsheibani, R. (2015). Informal self-employment in Kazakhstan. IZA Journal of Labor \& Development, 4, 1-19.

Nakhaie, R., Lin, X., \& Guan, J. (2009). Social capital and the myth of minority self-employment: evidence from Canada. Journal of Ethnic and Migration Studies, 35, 625-644.

Nichols, A. (2007). Causal inference with observational data. Stata Journal, 7, 507-541. 
Nikolova, E., Ricka, F., \& Simroth, D. (2012). Entrepreneurship in the transition region: an analysis based on the Life in Transition Survey. Working paper No. 114, London: European Bank for Reconstruction and Development.

Parker, S. (2009). The economics of entrepreneurship. Cambridge: Cambridge University Press.

Parker, S., \& Van Praag, C. (2006). Schooling, capital constraints, and entrepreneurial performance: the endogenous triangle. Journal of Business \& Economic Statistics, 24, 416-431.

Parker, S., \& van Praag, C. (2010). Status and entrepreneurship. Journal of Economics and Management Strategy, 19, 919-945.

Plug, E., \& Vijverberg, W. (2003). Schooling, family background, and adoption: is it nature or is it nurture? Journal of Political Economy, 111, 611-641.

Sabirianova, K. (2002). The great human capital relocation: an empirical analysis of occupational mobility in transition Russia. Journal of Comparative Economics, 30, 191-217.

Sargan, J. (1958). The estimation of economic relationships using instrumental variables. Econometrica, 26, $393-415$.

Silova, I., Johnson, M., \& Heyneman, S. (2007). Education and the crisis of social cohesion in Azerbaijan and Central Asia. Comparative Education Review, 51, 159-180.

Stock, J., Wright, J., \& Yogo, M. (2002). A survey of weak instruments and weak identification in generalized method of moments. Journal of Business \& Economic Statistics, 20, 518-529.

Tamasy, C. (2006). Determinants of regional entrepreneurship dynamics in contemporary Germany: a Conceptual and empirical analysis. Regional Studies, 40, 365-384.

Tamvada, J. (2010). The Dynamics of Self-employment in a Developing Country: Evidence from India. MPRA Paper No. 20042.

Uhlaner, L., \& Thurik, A. (2004). Post-materialism as a cultural factor influencing entrepreneurial activity across nations: a cultural factor influencing total entrepreneurial activity across nations. Papers on entrepreneurship, growth and public policy, (07/2004).

Vakhitova, H., \& Coupe, T. (2014). The relationship between education and labor market opportunities: the case of Ukraine. Free Policy Brief Series. March 2014.

Van der Sluis, J., Van Praag, M., \& Vijverberg, W. (2008). Education and entrepreneurship selection and performance: a review of the empirical literature. Journal of Economic Surveys, 22, 795-841.

van der Zwan, P., Zuurhout, P., \& Hessels, J. (2013). Entrepreneurship education and self-employment: The role of perceived barriers. Zoetermeer: Panteia/EIM Business and Policy Research.

Winship, C., \& Morgan, S. (1999). The estimation of causal effects from observational data. Annual Review of Sociology, 25, 659-706. 